\title{
Analisa MRR, EWR, DOC terhadap Beberapa Material Elektroda pada Proses EDM Die Sinking
}

\author{
Petrus Londa \\ Jurusan Teknik Mesin Politeknik Negeri Bandung \\ Jl. Geger Kalong Hilir, Ds. Ciwaruga, Bandung 40012, Telp. (022) 2013789. \\ E-mail: petruslonda@yahoo.com
}

\begin{abstract}
Electrical Discharge Machining (EDM) is a non-conventional machining process. EDM can cut all types of electrically conductive workpieces, mainly used on workpieces that very hard and have complex shapes, which cannot be cut by conventional machines. This study using the Taguchi method to determine machining variables that significantly affecting the cutting process in some electrode materials (copper, brass, aluminium) and workpieces from material $K 460$ (amutite S). Taguchi $L_{25}$ Orthogonal standard arrays and analysis of variance (ANOVA) can determine the performance of cutting variables (PON, $P O F F, G A P, Q D O N, S E R V O$ and LT) with the variables studied were Electrode Wear Rate (EWR), Material Removal Rate (MRR) and Overcut Diameter (DOC). The results of this study are displayed in the form of tables and graphs, which show the machining variables that significantly affecting the cutting process according to the type of electrode material used.
\end{abstract}

Keywords: ANOVA, DOC, EDM, EWR, Electrodes, MRR, Taguchi, Machining Variables.

\section{Abstrak}

Electrical Discharge Machining (EDM) adalah non-conventional machining process. EDM dapat memotong semua jenis benda kerja yang bersifat penghantar listrik, terutama digunakan pada benda kerja yang sangat keras dan memiliki bentuk yang rumit, yang tidak dapat dipotong oleh mesin konvensional. Penelitian ini menggunakan metode Taguchi untuk menentukan variabel pemesinan yang secara signifikan mempengaruhi proses pemotongan pada beberapa material elektroda (tembaga, kuningan, alumunium) dan benda kerja dari bahan K460 (amutit S). Taguchi L $_{25}$ Orthogonal standard arrays dan analysis of variance (ANOVA) dapat menentukan performa variabel pemotongan (PON, POFF, GAP, QDON, SERVO dan LT) dengan variabel yang diteliti adalah Electrode Wear Rate (EWR), Material Removal Rate (MRR) dan Diameter Overcut (DOC). Hasil dari penelitian ini ditampilkan dalam bentuk tabel-tabel dan grafik yang menunjukan variabel pemesinan yang signifikan mempengaruhi proses pemotongan sesuai dengan jenis material elektroda yang digunakan.

Kata kunci: ANOVA, DOC, EDM, EWR, Elektroda, MRR, Taguchi, Variabel pemesinan.

\section{Pendahuluan}

Proses EDM terutama digunakan pada pekerjaan-pekerjaan presisi dan bentuk yang rumit serta pada material yang sangat keras, seperti ceramics, maraging steels, cast-alloys, titanium [1]. Antara benda kerja dan elektroda tidak saling kontak secara fisik, melainkan terjadi loncatan bunga api listrik atau spark pada jarak terdekat antara elektroda dengan benda kerja atau yang di sebut spark gap [2]. Material elektroda dapat di kategorikan menjadi tiga, yaitu metallic, graphite dan paduan antara metallic dan graphite [3]. Proses pemotongan pada EDM ini seperti ditunjukan dalam Gambar 1. Pemotogan terjadi pada periode $\mathbf{U}$, pada peristiwa ini arus akan mengalir dengan durasi yang sangat cepat (terjadi peristiwa PON dan POFF secara bergantian), setelah itu elektroda akan mundur ketika memasuki periode $\mathbf{R}$, pada peristiwa ini geram-geram hasil pemotongan akan terbawa pergi oleh cairan dielektrik. Selanjutnya elektroda akan melakukan pemotongan lagi pada periode $\mathbf{U}$ yang berikutnya. Peristiwa ini akan terulang kembali sampai mencapai kedalaman pemotongan yang di inginkan.

Selanjutnya, setelah terjadinya loncatan bunga api listrik; aliran listrik terhenti, menyebabkan penurunan temparatur secara mendadak dan mengakibatkan gelembung uap mengkerut sehingga bagian benda kerja dan elektroda yang meleleh akan terpancar keluar (terjadi erosi) dan meninggalkan bekas-bekas berupa kawah halus pada permukaan material. Proses erosi yang terjadi pada elektroda menyebabkan keausan elektroda atau electrode wear rate (EWR), sedangkan proses erosi pada benda kerja merupakan proses pengerjaan benda kerja, produktivitas pengerjaan benda kerja di tunjukan oleh material removal rate (MRR) [5]. Proses erosi pada permukaan benda kerja dan elektroda tersebut tergantung pada variabel-variabel pemesinan, pada mesin EDM Neu-ar type ZNC variabel-variabel tersebut adalah : (i) Polaritas (+/-), (ii) Konduktivitas panas dari material, (iii) Titik leleh, (iv) Interval waktu (POFF), (v) Intensitas dari loncatan bunga api listrik (PON), (vi) QDON, (vii) QUP, (viii) SPD, (ix) SERVO, (x) GAP, (xi) LT. Variabel pemesinan yang digunakan pada penelitian ini adalah LT, PON, POFF, QDON, SERVO dan GAP dengan tujuan untuk mengetahui laju keausan dari tiga jenis elektroda dan laju keausan benda kerja, serta Diameter Overcut (DOC). Studi tentang keausan ini sudah di 
lakukan oleh beberapa peneliti seperti Priyesh N. Santoki pada 2015, beliau menganalisa MRR yang dipengaruhi oleh elektroda tembaga, graphite dan silver pada benda kerja AISI 304 Stainless Steel (SS-304) [6]. Begitu juga yang dilakukan oleh Dhanabalan S., dkk. pada 2015, mereka melakukan eksperimen dengan menggunakan elektroda tembaga, kuningan dan aluminium pada material titanium alloy untuk mengetahui EWR, MRR dan SR. Adapun variabel pemesinan yang mereka gunakan adalah current, pulse on time (PON) dan pulse off time (POFF) [7]. Selain itu studi tentang Diameter Overcut (DOC) juga dilakukan oleh Prabhjot Balraj Singh, dkk pada Januari 2015. Mereka menggunakan istilah Radial Overcut (ROC) pada material H-13 steel dan elektroda dari bahan cryogenic cooled [8].

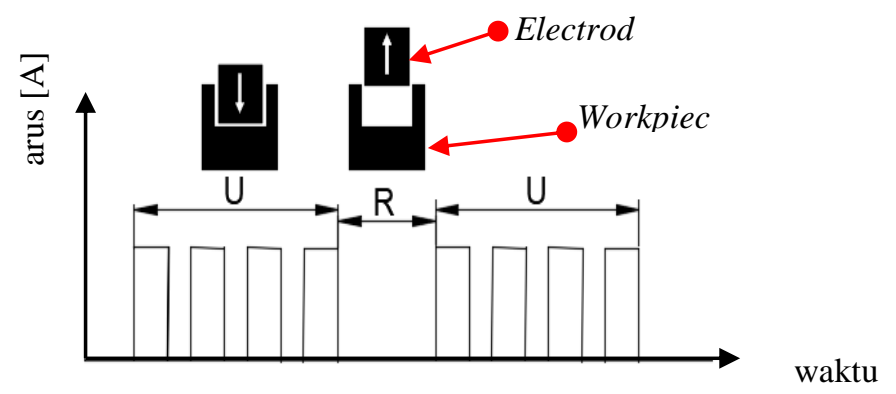

Gambar 1. Mekanisme Proses Pemotongan [4]

2. Material dan metodologi

2.1. Metode Eksperimen

Eksperimen di lakukan untuk mengetahui keausan pada elektroda atau Electrode Wear Rate dan keausan pada benda kerja atau Material Removal Rate dan juga untuk mengetahui Diameter Overcut (DOC). Eksperimen di lakukan dengan menggunakan mesin EDM Neu-ar type ZNC yang ada di Politeknik Negeri Bandung, seperti yang di perlihatkan pada Gambar 2a dan proses setup mesin ditunjukan dalam Gambar 2b. Mesin EDM ini memiliki kapasitas cairan dielektrik 300 liter. Menggunakan DC servo untuk menghasikan tegangan listik untuk pemotongan benda kerja. Benda kerja terendam di dalam cairan dielektrik dan diberi penyemprotan dari samping dengan tekanan 8 psi. untuk mempermudah mengeluarkan geram sisa pemotongan. Sedangkan MRR dan EWR adalah perbedaan berat benda kerja dan berat elektroda sebelum dan sesudah proses pemesinan dan di hitung dalam satuan gram.

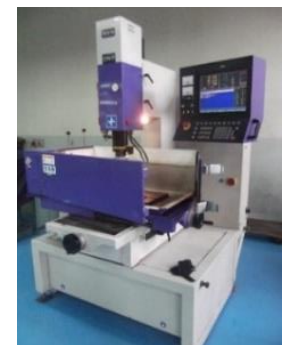

(2a)

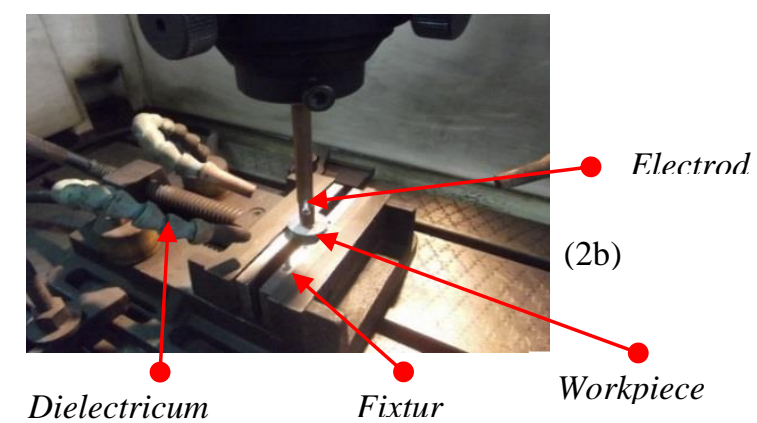

Gambar 2. Mesin EDM Neu-ar type ZNC dan setup

\subsection{Alat dan bahan penelitian}

Bahan yang di perlukan dalam penelitian ini adalah: (i) Elektroda dari tembaga, kuningan dan aluminium masingmasing berdiameter $10 \mathrm{~mm}$ dengan komposisi kimia seperti dalam Tabel 1. (ii) Fluida dielektrik kerosene dengan viskositas 2 Cst dan titik api $78^{\circ} \mathrm{C}$. (iii) Benda kerja dari baja perkakas K460 (amutit S) dengan kekerasan 66 HRC, komposisi kimia di perlihatkan dalam Tabel 2. Sedangkan bentuk dan ukuran yang dihasilkan adalah lubang tidak tembus (buntu) dengan ukuran diameter $10 \mathrm{~mm}$ dan kedalaman $2 \mathrm{~mm}$. Hasil eksperimen diperlihatkan dalam Gambar 3a untuk benda kerja dan elektroda tembaga, Gambar $3 b$ untuk benda kerja dan elektroda kuningan, Gambar 3c untuk benda kerja dan elektroda aluminium, (iv) Alat-alat yang digunakan seperti jangka sorong digital dengan ketelitian 0,02 mm dan timbangan digital berkapasitas 300 gram dengan ketelitian 0,01 gram.

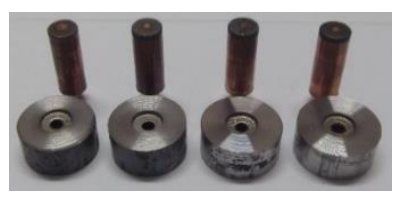

(a)

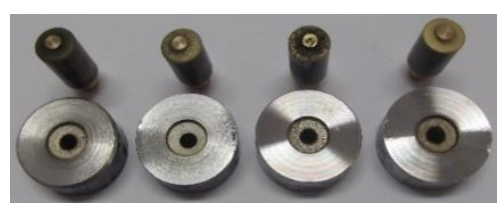

(b)

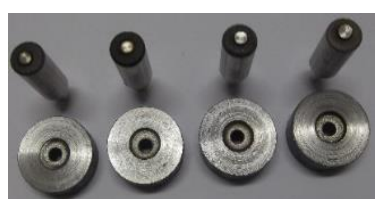

(c)

Gambar 3. Hasil eksperimen eletroda tembaga, kuningan dan aluminium 
Tabel 1. Komposisi kimia untuk material elektroda.

\begin{tabular}{ccccccc}
\hline \multirow{2}{*}{ No. } & \multicolumn{2}{c}{ Tembaga } & \multicolumn{2}{c}{ Kuningan } & \multicolumn{2}{c}{ Aluminium } \\
\cline { 2 - 7 } & Unsur Kimia & Komposisi (\%) & Unsur Kimia & Komposisi (\%) & Unsur Kimia & Komposisi (\%) \\
\hline 1. & $\mathrm{Sn}$ & 0,055 & $\mathrm{Sn}$ & 0,69912 & $\mathrm{Si}$ & 0,07591 \\
2. & $\mathrm{Zn}$ & 0,023 & $\mathrm{Zn}$ & 39,90655 & $\mathrm{Fe}$ & 0,23941 \\
3. & $\mathrm{~Pb}$ & 0,009 & $\mathrm{~Pb}$ & 2,86303 & $\mathrm{Cu}$ & 0,00719 \\
4. & $\mathrm{Fe}$ & 0,024 & $\mathrm{Fe}$ & 0,50726 & $\mathrm{Mn}$ & 0,65609 \\
5. & $\mathrm{Ni}$ & 0,008 & $\mathrm{Ni}$ & 0,39704 & $\mathrm{Mg}$ & 3,98841 \\
6. & $\mathrm{Al}$ & 0,049 & $\mathrm{Al}$ & 0,20588 & $\mathrm{Zn}$ & 0,00658 \\
7. & $\mathrm{P}$ & 0,002 & $\mathrm{P}$ & 0,00556 & $\mathrm{Ti}$ & 0,06681 \\
8. & $\mathrm{Si}$ & 0,004 & $\mathrm{Si}$ & 0,01984 & $\mathrm{Cr}$ & 0,08302 \\
9. & $\mathrm{Mn}$ & 0,001 & $\mathrm{Mn}$ & 0,02881 & $\mathrm{Ni}$ & 0,00453 \\
10. & $\mathrm{~S}$ & 0,000 & $\mathrm{~S}$ & 0,00329 & $\mathrm{Sn}$ & 0,00026 \\
11. & $\mathrm{Sb}$ & 0,006 & $\mathrm{Sb}$ & 0,04555 & $\mathrm{Zr}$ & 0,00105 \\
12. & $\mathrm{Cu}$ & 99,820 & $\mathrm{Mg}$ & 0,00112 & $\mathrm{~V}$ & 0,00564 \\
13 & & & $\mathrm{Cu}$ & 55,31690 & $\mathrm{Sb}$ & 0,00686 \\
14 & & & & $\mathrm{Al}$ & 94,90950 \\
\hline
\end{tabular}

Tabel 2. Komposisi kimia untuk material benda kerja

\begin{tabular}{cccc}
\hline No. & Unsur kimia & Komposisi $(\boldsymbol{\%})$ & Kekerasan \\
\hline 1. & $\mathrm{C}$ & 0,95 & \\
2. & $\mathrm{Si}$ & 0,25 & \\
3. & $\mathrm{Mn}$ & 1,10 & 66 HRC \\
4. & $\mathrm{Cr}$ & 0,55 & \\
5. & $\mathrm{~V}$ & 0,10 & \\
6. & $\mathrm{~W}$ & 0,55 & \\
\hline
\end{tabular}

\subsection{Bentuk elektroda dan benda kerja}

Bentuk elektroda di rancang sedemikian rupa sehingga mudah dalam penggunaan. Bentuk elektroda dan tangkai elektroda seperti yang diperlihatkan dalam Gambar 4a, bentuk demikian mempermudah dalam pergantian elektroda dimana pada tangkai elektroda di lengkapi dengan baut pengunci elektroda. Sedangkan bentuk benda kerja adalah bulat dengan diameter $25 \mathrm{~mm}$, tebal $10 \mathrm{~mm}$ dan ke dua permukaan pada arah aksial di gerinda agar nampak lebih halus. Sedangkan pada pusat diameter di buat lubang tembus dengan diameter $4 \mathrm{~mm}$ untuk mempermudah aliran geram sisa pemotongan. Bentuk benda kerja di tunjukan dalam Gambar $4 \mathrm{~b}$.
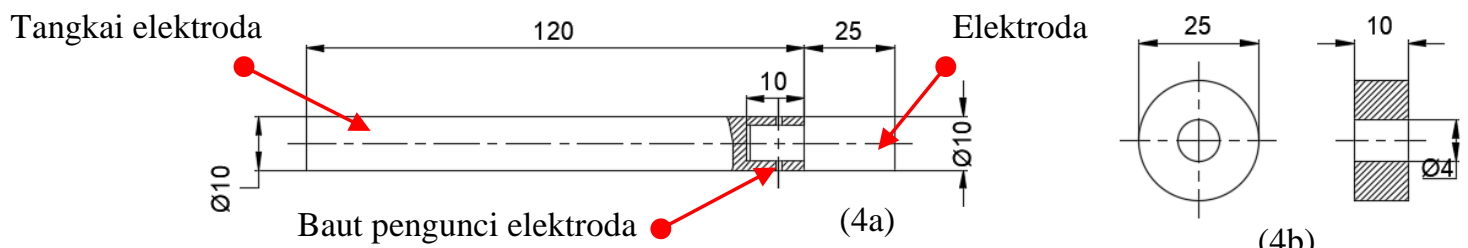

(4b)

Gambar 4. Tangkai elektroda dan benda kerja.

\subsection{Rancangan penelitian}

Paper ini menggunakan metode Taguchi untuk pengambilan data karena metode ini sangat efektif dalam mengambil keputusan terhadap suatu penelitian dengan multi parameter [9]. Pemilihan variabel proses EDM sebagai berikut:

a. Variabel yang di tetapkan

Sistem saluran pembawa partikel (geram) hasil pemotongan adalah terendam dalam cairan dielektrik dengan sedikit penyemprotan dari samping, polaritas (+) pada elektroda, kecepatan gerak spindel mesin (SPD =60\%), langkah bebas elektroda terhadap benda kerja setiap siklus (QUP = 1,5 mm).

b. Variabel bebas (input variable)

Variabel bebas terdiri dari current (LT), intensitas loncatan bunga api listrik atau Pulse-on time (PON), interval waktu pelepasan energi listrik atau Pulse-off time (POFF), lama waktu discharge (QDON), sensitifitas selama proses pemesinan (SERVO) dan gap voltage (GAP). Nilai dari masing-masing variabel pemesinan tersebut di bagi menjadi lima level, seperti yang diperlihatkan dalam Table 3. 
Tabel 3. Nilai setiap level untuk input variable.

\begin{tabular}{|c|c|c|c|c|c|c|}
\hline No. & Variabel pemotongan & Level 1 & Level 2 & Level 3 & Level 4 & Level 5 \\
\hline 1 & $\mathrm{LT}[A]$ & 3 & 6 & 12 & 21 & 45 \\
\hline 2 & $\mathrm{PON}[\mu s]$ & 8 & 20 & 60 & 400 & 700 \\
\hline 3 & $\mathrm{POFF}[\mu s]$ & 4 & 6 & 8 & 10 & 12 \\
\hline 4 & QDON [sec.] & 1 & 3 & 6 & 9 & 12 \\
\hline 5 & SERVO [\%] & 10 & 40 & 50 & 70 & 80 \\
\hline 6 & GAP [volt $]$ & 25 & 35 & 45 & 65 & 85 \\
\hline
\end{tabular}

c. Respon variabel: respon variabel adalah variabel yang di teliti (output variable) yaitu Electrode Wear Rate (EWR), Diameter Overcut (DOC) dan Material Removal Rate (MRR).

Skema eksperimen berdasarkan metode Taguchi $L_{25}$ orthogonal standard arrays [10] diperlihatkan dalam Tabel 4 yang terdiri dari 6 kolom variabel pemesinan, 25 baris menunjukan nomor eksperimen; pada penelitian ini jumlah eksperimen adalah 25 baris x 6 pasangan variabel. Setiap variabel pemesinan di uji terhadap variasi variabel pasangannya, sehingga total eksperimen sebanyak 150 kali eksperimen. Nilai yang berada pada setiap matriks dalam Table 4 menunjukan level dari masing-masing variabel pemesinan.

Tabel 4. Skema eksperimen $L_{25}$ orthogonal standard array

\begin{tabular}{|c|c|c|c|c|c|c|}
\hline \multirow{2}{*}{ No. eks. } & \multicolumn{6}{|c|}{ Variabel Pemesinan } \\
\hline & LT & PON & POFF & QDON & SERVO & GAP \\
\hline 1 & 1 & 1 & 1 & 1 & 1 & 1 \\
\hline 2 & 1 & 2 & 2 & 2 & 2 & 2 \\
\hline 3 & 1 & 3 & 3 & 3 & 3 & 3 \\
\hline 4 & 1 & 4 & 4 & 4 & 4 & 4 \\
\hline 5 & 1 & 5 & 5 & 5 & 5 & 5 \\
\hline 6 & 2 & 1 & 2 & 3 & 4 & 5 \\
\hline 7 & 2 & 2 & 3 & 4 & 5 & 1 \\
\hline 8 & 2 & 3 & 4 & 5 & 1 & 2 \\
\hline 9 & 2 & 4 & 5 & 1 & 2 & 3 \\
\hline 10 & 2 & 5 & 1 & 2 & 3 & 4 \\
\hline 11 & 3 & 1 & 3 & 5 & 2 & 4 \\
\hline 12 & 3 & 2 & 4 & 1 & 3 & 5 \\
\hline 13 & 3 & 3 & 5 & 2 & 4 & 1 \\
\hline 14 & 3 & 4 & 1 & 3 & 5 & 2 \\
\hline 15 & 3 & 5 & 2 & 4 & 1 & 3 \\
\hline 16 & 4 & 1 & 4 & 2 & 5 & 3 \\
\hline 17 & 4 & 2 & 5 & 3 & 1 & 4 \\
\hline 18 & 4 & 3 & 1 & 4 & 2 & 5 \\
\hline 19 & 4 & 4 & 2 & 5 & 3 & 1 \\
\hline 20 & 4 & 5 & 3 & 1 & 4 & 2 \\
\hline 21 & 5 & 1 & 5 & 4 & 3 & 2 \\
\hline 22 & 5 & 2 & 1 & 5 & 4 & 3 \\
\hline 23 & 5 & 3 & 2 & 1 & 5 & 4 \\
\hline 24 & 5 & 4 & 3 & 2 & 1 & 5 \\
\hline 25 & 5 & 5 & 4 & 3 & 2 & 1 \\
\hline
\end{tabular}

Prosedur penelitian meliputi tahapan-tahapan sebagai berikut: (i) mengukur berat awal masing-masing elektroda dan benda kerja dengan menggunakan timbangan, (ii) melakukan proses pengujian pada mesin EDM dengan pasangan variabel yang telah di tetapkan, (iii) mengukur masing-masing berat elektroda dan benda kerja setelah proses pengujian untuk mengetahui selisih berat dan mengukur diameter yang dihasilkan, (iv) menghitung semua hasil pengukuran yang di perlukan dengan menggunakan persamaan.

a. Metode Taguchi:

Metode Taguchi digunakan untuk menentukan efek dari enam variabel proses EDM (LT, PON, POFF, QDON, SERVO, GAP) terhadap tiga variabel output (EWR, MRR, DOC). Untuk mengukur interaksi dari ke enam variabel tersebut maka di gunakan pendekatan signal-to-noise ratio ( $S / N$ ratio). Untuk menghitung $S / N$ ratio pada keausan elektroda menggunakan aturan smaller-the-better (STB) quality characteristic dengan persamaan:

$$
\frac{s}{N}=-10 \log \left[\frac{1}{n} \sum_{i=1}^{n} y_{i}^{2}\right]
$$


dimana $n$ adalah jumlah data yang diobservasi dan $y_{i}$ adalah data ke $i$, sedangkan untuk menghitung $S / N$ ratio pada keausan benda kerja menggunakan aturan larger-the-better (LTB) quality characteristic dengan persamaan:

$\frac{s}{N}=-10 \log \left[\frac{1}{n} \sum_{i=1}^{n} \frac{1}{y_{i}^{2}}\right]$

Nilai setiap level dapat di hitung dengan persamaan:

Nilai level $=\frac{\text { jumlah nilai } \frac{\text { s }}{N} \text { ratio setiap baris di dalam level }}{\text { jumlah baris di dalam level }}$

b. Analysis of variance (ANOVA)

ANOVA dapat menunjukan persentase keausan dari masing-masing material yang digunakan dan dapat menunjukan tingkat kepercayaan dari suatu analisa. Pada penelitian ini ditetapkan tingkat kepercayaan pada level 5\%. Adapun parameter yang di hitung seperti sum of square group, degree of freedom, variance dan nilai kontribusi dari setiap parameter pemesinan pada analisa regresi. Penggunaan ANOVA memang cukup sulit karena berhubungan dengan rumus-rumus statistik seperti ditunjukan dalam persamaan 4, 5 dan 6, namun untuk menganalisa data dalam penelitian ini menggunakan data analisa dari excel 2016 dengan two way ANOVA with replication.

- Menentukan jumlah kuadrat dari data (Sum of Square Group)

$\operatorname{SoS}_{\text {Group }}=\sum_{i=1}^{k} \frac{T_{* i}^{2}}{n_{i}}-\frac{\left(T_{* *}\right)^{2}}{N}$

dimana $k$ adalah jumlah kolom, $n_{i}$ banyaknya data pada kolom ke $i, N$ adalah data keseluruhan, $T *_{*}$ adalah jumlah data pada kolom ke $i$ dan $T *$ adalah jumlah $T_{* i}$.

- Menentukan jumlah kuardat tengah (Mean Square)

$M S=\frac{S_{\text {Group }}}{D F}$

dimana DF adalah Degree of Freedom $(k-1)$.

- Menentukan koefisien regresi menggunakan persamaan multiple linear regression

$Y=\beta_{0}+\beta_{1} \cdot x_{1}+\beta_{2} \cdot x_{2}+\beta_{3} \cdot x_{3}+\ldots \ldots+\beta_{p} \cdot x_{p}+\varepsilon$

dimana $Y$ adalah dependent variable, $x_{1}, x_{2}, \ldots x_{p}$ adalah independent variable, $\beta_{0}$ adalah konstanta, $\beta_{1}, \beta_{2}, \ldots . \beta_{p}$ adalah regression variable dan $\varepsilon$ adalah error. Regresi linier berganda digunakan untuk mengevaluasi pengaruh variabel pemotongan terhadap Diameter Overcut (DOC) dan menentukan persamaan regresi dari DOC.

\section{Hasil dan pembahasan}

a. Analisa Taguchi

Setelah melakukan eksperimen, maka di peroleh data keausan elektroda (EWR) dan data keausan benda kerja (MRR) serta data Diameter overcut (DOC) untuk setiap variabel pasangannya. Data-data tersebut di hitung dengan menggunakan persamaan (1) untuk elektroda, persamaan (2) untuk benda kerja dan nilai level persamaan (3), sedangkan untuk menentukan variabel pemesinan yang secara signifikan mempengaruhi ketahanan terhadap keausan elektroda dapat di tentukan dengan selisih nilai rata-rata terbesar dikurangi nilai rata-rata terkecil dari setiap level S/N ratio ( $m e a n ~ S / N ~ r a t i o)$. Selisih nilai tersebut untuk masing-masing elektroda seperti yang ditunjukan dalam Table 5.

Tabel 5. Signifikan parameter pemesinan untuk EWR.

\begin{tabular}{llccc}
\hline \multirow{2}{*}{ No. } & \multirow{2}{*}{$\begin{array}{l}\text { Machining } \\
\text { parameters }\end{array}$} & \multicolumn{3}{c}{$\begin{array}{c}\text { Significance of machining parameters } \\
(\text { Max }- \text { Min })\end{array}$} \\
\cline { 3 - 5 } & & Elektrod tembaga & Elektroda kuningan & Elektroda aluminium \\
\hline 1. & LT & 20.95756 & 1.469708 & 3.795390 \\
2. & PON & 23.86899 & 2.268670 & 6.075072 \\
3. & POFF & 7.280642 & 9.010765 & 15.523679 \\
4. & QDON & 10.07262 & 5.276370 & 18.501459 \\
5. & SERVO & 8.135114 & 6.848314 & 7.555161 \\
6. & GAP & 10.22062 & 7.629913 & 12.332263 \\
\hline
\end{tabular}


Sebaliknya pada benda kerja diharapkan keausan yang maksimal, sehingga untuk menghitung $S / N$ ratio pada setiap level kita gunakan aturan LTB quality characteristic, sedangkan untuk menentukan variabel pemesinan yang secara signifikan mempengaruhi keausan benda kerja dapat di tentukan dengan selisih nilai rata-rata terbesar dikurangi nilai ratarata terkecil dari setiap level $S / N$ ratio (mean $S / N$ ratio). Selisih nilai tersebut untuk masing-masing elektroda yang memotong benda kerja seperti yang ditunjukan dalam Table 6.

Tabel 6. Signifikan parameter pemesinan untuk MRR, Benda kerja (K460)

\begin{tabular}{ccccc}
\hline \multirow{2}{*}{ No. } & \multirow{2}{*}{$\begin{array}{c}\text { Machining } \\
\text { parameters }\end{array}$} & \multicolumn{3}{c}{$\begin{array}{c}\text { Significance of machining parameters } \\
\text { (Max-Min) }\end{array}$} \\
\cline { 3 - 5 } & & Elektrod tembaga & Elektroda kuningan & Elektroda aluminium \\
\hline 1. & LT & 2.708026 & 2.100884 & 4.109834 \\
2. & PON & 6.015958 & 5.472836 & 5.472836 \\
3. & POFF & 11.86796 & 5.928073 & 5.928073 \\
4. & QDON & 7.467375 & 2.959388 & 2.959388 \\
5. & SERVO & 6.412955 & 4.988358 & 4.988358 \\
6. & GAP & 7.671720 & 13.89944 & 17.646348 \\
\hline
\end{tabular}

b. Analysis of Variance (ANOVA)

Metode taguchi belum dapat menunjukan persentase keausan dari masing-masing elektroda, oleh sebab itu gunakan ANOVA untuk menentukan persentase keausan dari masing-masing elektroda tersebut. Analisis ANOVA untuk Electrode Wear Rate (EWR) dan Material Removal Rate (MRR) ditampilkan dalam Table 7 dan Table 8.

Tabel 7. Analisis ANOVA untuk EWR

\begin{tabular}{|c|c|c|c|c|c|c|c|c|}
\hline No. & Sample & $d F$ & Sum of squares & Mean squares & $F$ & P-value & $F$ crit & $\%$ wear \\
\hline 1. & Tembaga & 4 & 0.11371 & 0.02843 & 0.51772 & 0.72285 & 2.44724 & 1.85 \\
\hline 2. & Kuningan & 4 & 0.36371 & 0.09093 & 3.55210 & 0.00892 & 2.44724 & 5.90 \\
\hline 3. & Aluminium & 4 & 5.68610 & 1.42153 & 1.95223 & 0.10766 & 2.46261 & 92.25 \\
\hline & Total & 12 & 6.16352 & 1.54089 & & & & 100 \\
\hline
\end{tabular}

Tabel 8. Analisis ANOVA untuk MRR

\begin{tabular}{|c|c|c|c|c|c|c|c|c|}
\hline No. & Sample & $d F$ & Sum of squares & Mean squares & $F$ & $P$-value & $F$ crit & $\%$ wear \\
\hline 1. & Tembaga & 4 & 0.54949 & 0.13737 & 1.84566 & 0.12602 & 2.46261 & 14.94 \\
\hline 2. & Kuningan & 4 & 0.20255 & 0.05064 & 3.34504 & 0.01294 & 2.46261 & 5.51 \\
\hline \multirow[t]{2}{*}{3.} & Aluminium & 4 & 2.92517 & 0.73129 & 3.48910 & 0.01037 & 2.46261 & 79.55 \\
\hline & Total & 12 & 3.67721 & 0.91930 & & & & 100 \\
\hline
\end{tabular}

\section{c. Regresi linier}

Analisa regresi digunakan untuk melihat penyimpangan diameter yang dihasilkan (DOC). Diameter dari ke tiga jenis elektroda adalah $10 \mathrm{~mm}$, lubang yang dihasilkan diukur menggunakan jangka sorong digital dengan ketelitian 0,02 mm. Persentase penyimpangan dalam analisa ini ditampilkan dalam Table 9 dan bentuk-bentuk penyimpanganya ditampilkan dalam grafik yang di ambil dari pasangan veriabel pemotongan SERVO dan diperlihatkan dalam Gambar 5, 6 dan 7. Pasangan variabel pemotongan SERVO terdiri dari lima level dan nilainya dapat dilihat pada Tabel 3, sedangkan variasi pengujian setiap levelnya ditunjukan dalam Tabel 10.

Tabel 9. Analisis Regresi linier untuk DOC

\begin{tabular}{|c|c|c|c|c|c|c|c|}
\hline No. & Sample & $d F$ & Sum of squares & Mean squares & $F$ & Significance $F$ & $\%$ DOC \\
\hline 1. & Tembaga & 6 & 0.01978 & 0.00330 & 0.97497 & 0.46992 & 25.72 \\
\hline 2. & Kuningan & 6 & 0.01848 & 0.00308 & 0.97775 & 0.46827 & 24.03 \\
\hline 3. & Aluminium & 6 & 0.03864 & 0.00644 & 0.98537 & 0.46376 & 50.25 \\
\hline & Total & 18 & 0.07690 & 0.01282 & & & 100 \\
\hline
\end{tabular}

Tabel 10. Nilai level variabel pemotongan SERVO

\begin{tabular}{cc}
\hline Level & Nilai variable pemotongan SERVO \\
\hline Level 1 & $10,40,50,70,80$ \\
Level 2 & $50,70,80,10,40$ \\
Level 3 & $80,1040,50,70$ \\
Level 4 & $40,50,70,80,10$ \\
Level 5 & $70,80,10,40,50$ \\
\hline
\end{tabular}


Efek dari servo voltage terhadap MRR dipengaruhi oleh durasi arus yang mengalir dan variabel pemotongan lainya, seperti POFF. Meningkatnya laju keausan benda kerja (MRR) seiring dengan meningkatnya servo voltage [11]. Grafikgrafik pada Gambar 5, 6 dan Gambar 7 memperlihatkan pengaruh variabel SERVO terhadap perubahan diameter lubang benda kerja.

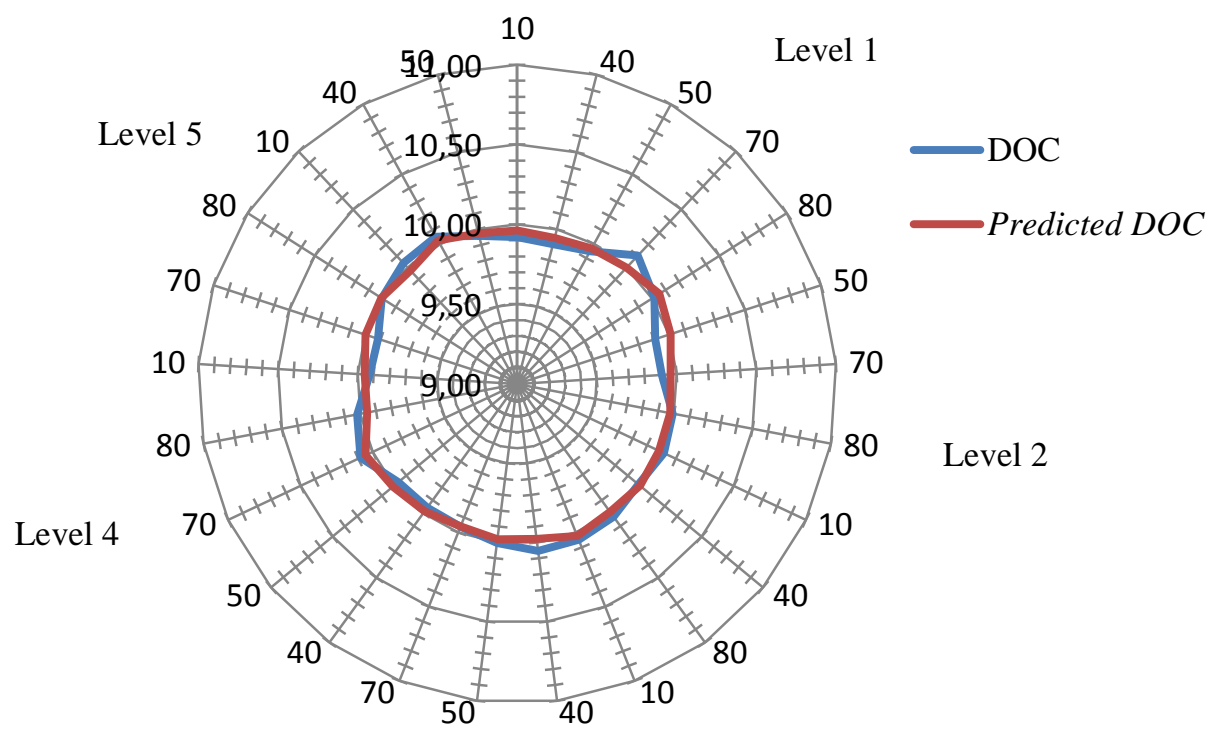

Level 3

Gambar 5. Grafik regresi DOC vs SERVO untuk elektroda

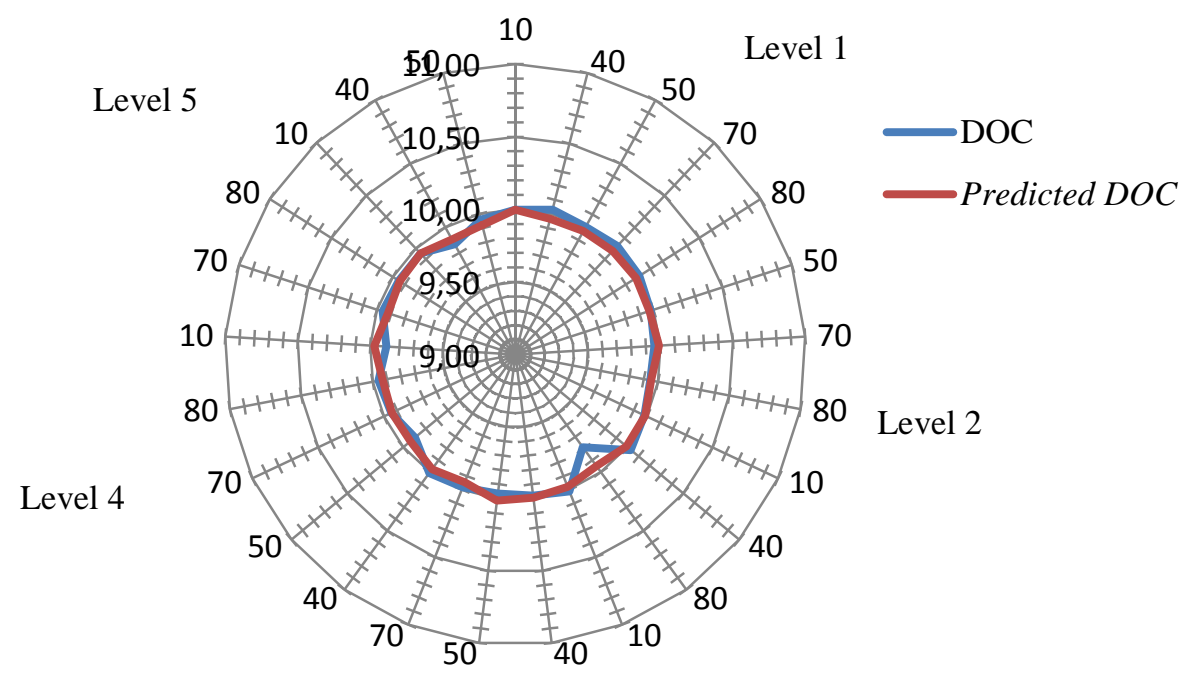

Level 3

Gambar 6. Grafik regresi DOC vs SERVO untuk elektroda kuningan. 


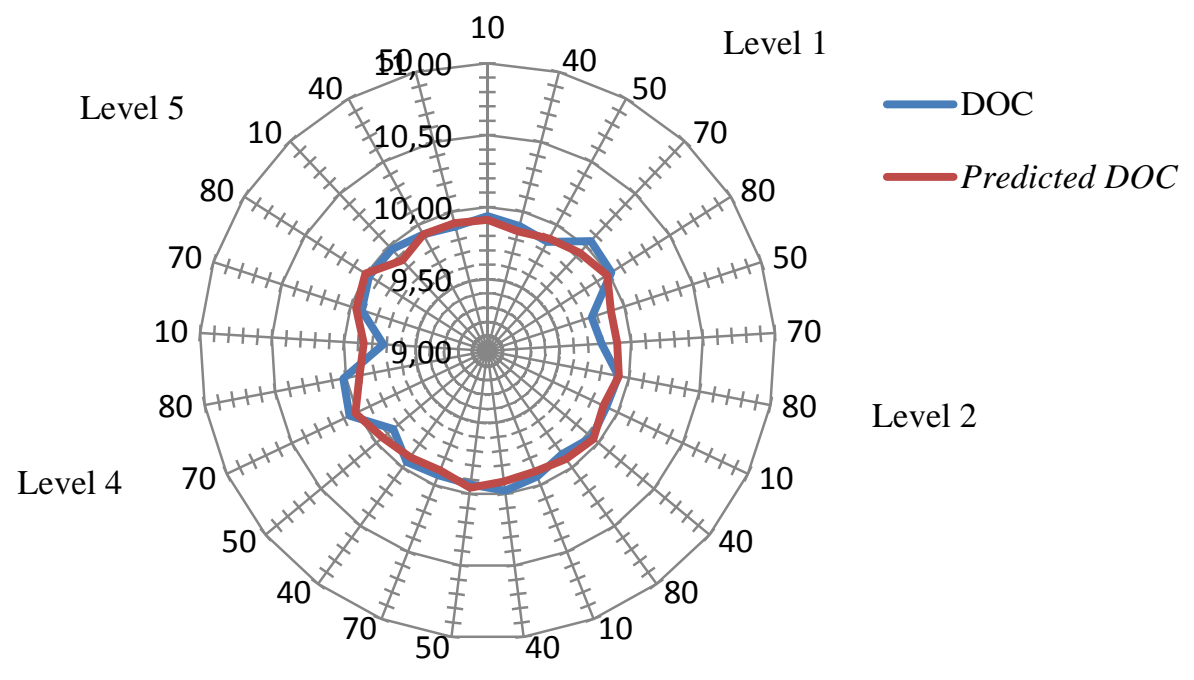

Level 3

Gambar 7. Grafik regresi DOC vs SERVO untuk elektroda aluminium.

\section{Kesimpulan}

Analisa Taguchi menunjukan bahwa variabel pemotongan yang sangat mempengaruhi ketahanan terhadap keausan elektroda, masing-masing PON 23.86899 untuk elektroda tembaga, QDON 18.501459 untuk elektroda aluminium dan POFF 9.010765 untuk elektroda kuningan, hal tersebut dapat dilihat pada Tabel 5, sedangkan variable pemotongan yang sangat mempengaruhi keausan benda kerja adalah POFF 11.86796 untuk elektroda tembaga, GAP 13,89944 untuk elektroda kuningan dan aluminium 17.646348, hal tersebut dapat dilihat pada Tabel 6. Analisa ANOVA menunjukan bahwa elektroda aluminium sangat tinggi keausanya $(92,25 \%)$ di bandingkan dengan elektroda kuningan $(5,90 \%)$ dan tembaga $(1,85 \%)$, hal tersebut dapat dilihat pada Tabel 7, sedangkan pada MRR prodktivitas pengerjaan benda kerja sangat bagus ditunjukan oleh elektroda aluminium (79,55\%) diikukuti oleh tembaga $(14,94 \%)$ dan kuningan $(5,51 \%)$, seperti ditunjukan dalam Tabel 8. Penyimpangan DOC pada elektroda aluminium mencapai 50,25\% diikuti dengan tembaga $25,72 \%$ dan kuningan $24,03 \%$. Elektroda aluminium produktivitas pengerjaan benda kerjanya sangat bagus, namun keausanya tinggi, DOC-nya tidak baik. Elektroda tembaga produktivitas pengerjaan benda kerjanya bagus, keausan rendah. Elektroda kuningan produktivitas rendah, keausan tinggi, cukup bagus untuk DOC.

\section{Referensi}

[1] Chandramouli S., dkk., 2014, "Optimization of Electrical Discharge Machining Process Parameters Using Taguchi Method”, International Journal of Advanced Mechanical Engineering, ISSN 2250-3234 Volume 4, pp. 425-434.

[2] Ghazey Ghanem Nagham. dkk., 2017, "Effect of Current, Pulse Duration, and Pulse Interval for Different Electrodes Shape on Electrode Wear Rate in EDM", International Journal of Research science \& Management, ISSN 234-5197.

[3] Banker K. S., dkk., 2013, "Performance Capabilities of EDM Machining Using Aluminium, Brass and Copper for AISI 304L Material", International Journal of Application or Innovation in Engineering \& Management (IJAIEM)", Volume 2, ISSN $2319-4847$.

[4] Amorim Fred L., dkk., 2007, "The Beahvior of Graphite and Copper Electrodes on the Finish Die-Shinking Electricak Discharge Machining (EDM) of AISI P20 Tool Steel”, Vol. XXIX, No.4, Pontifical Katholic University of Parana - PUCPR, Departement of Mechanical Engineering, Brazil.

[5] Gostimirovic Marin, dkk., 2012, "Influence of discharge energy on machining characteristics in EDM", Journal of Mechanical Science and Technology, 26(1)(2012)173 179, Springer.

[6] Priyesh N. Santoki, 2015, "An Experimental Study for Material Removal Rate in EDM using tool of graphite , copper \& silver”, International Journal for Research in Education (IJRE) (Impact Factor 1.5), ICV: 6.30, Vol. 4, Issue:1, (IJRE) ISSN: (P) 2347-5412 ISSN: (O) 2320-091X.

[7] Dhanabalan S., dkk., 2015, "Experimental Investigation on Electrical Discharge Machining of Titanium Alloy Using Copper, Brass and Aluminium Electrodes", Journal of Engineering Science and Technology, oSchool of Engineering, Taylor's University, Vol. 10, N0. 1 (2015) 72 - 80.

[8] Jeevamalar J., Ramabalan S., 2015, "Die Sinking EDM Process Parameters: a Review", International Journal of Mechanical Engineering and Robotics Research, vol. 4, ISSN 2278 - 0149. 
[9] Sandeep Kumar, 2013, "Current Research Trends in Electrical Discharge Machining: A Review”, Research Journal of Engineering Sciences, Vol. 2(2), 56-60, ISSN 2278 - 9472.

[10] Ross J. Phillip, 1996, "Taguchi Techniques for Quality Engineering”, 2 ${ }^{\text {nd }}$ Ed, McGraw-Hill, New York San Francisco Washington D.C. Ghazey.

[11] Muthukumar V., dkk, 2014, "Mathematical Modeling for Radial Overcut on Electrical Discharge Machining of Incoloy 800 by Response Surface Methodology", International Conference on Materials Processing and Characterisation, Procedia Materials Science 6 ( 2014 ) 1674 - 1682. 